\title{
Triple Deficits and Economic Growth in Kenya
}

\author{
Sandra Macharia ${ }^{1}$, Tabitha Nasieku, Ph.D. ${ }^{2}$ \\ ${ }^{1}$ School of Business, Jomo Kenyatta University of Agriculture and Technology, Kenya \\ ${ }^{2}$ School of Business, Jomo Kenyatta University of Agriculture and Technology, Kenya
}

\begin{abstract}
The objective of this study was to determine the effect of triple deficits on economic growth in Kenya. The specific objectives of the study were: to establish the effect of budget deficits, current account deficits and savings investments deficits on economic growth in Kenya.Persistent deficits have been of great concern because of the internal and external vulnerabilities they pose to the Kenyan economy. The study was based on the Keynesian theory, Thirlwall's theory, and endogenous growth model theory. Annual data ranging from the year 1990 to 2018 was used.The autoregressive distributed lag (ARDL) and error correction model (ECM) were used to establish the significance and impact of the variables on economic growth in Kenya in the short and long run. The research established that budget deficits had a significant effect on economic growth in the long run while current account deficits had a significant effect on economic growth in the short run. The study recommends adoption of macroeconomic policies that aim at reducing budget and current account deficits and encourage greater discipline to ensure optimal use of funds into productive sectors.
\end{abstract}

KEYWORDS: Triple deficits, Budget deficits, Current account deficits, Savings investments deficits, Economic growth

\section{INTRODUCTION}

The concept of triple deficits in an economy comes from the triple deficit hypothesis which states that; budget deficits, current account deficits and savings investments deficits will occur and move together (Sen and Kaya, 2016). (Mohamed, 2014) defined economic growth as the continuous increase in potential output of a country as measured by the increase in real gross domestic product (GDP) which is adjusted for inflation over a period.Economic growth is influenced by both direct factors which include human resources, natural resources, capital employed, technological advancements, and indirect factors which include aggregate demand, savings rates, investments rates, financial system efficiency, budgetary and fiscal policies, external factors, and government efficiency (Boldeanu and Constantinescu, 2015). Empirical studies on the effect of triple deficits on economic growth have yielded mixed results with some proving a negative link and others proving a positive link.

On one hand, persistent budget, current account, and savings investments deficits are deemed to cause instabilities in an economy. These instabilities may take the form of high interest rates, increased borrowing by the government which may lead to crowding out of private investors, indebtedness, appreciation of the currency which negatively affects a country's exports and inflation (Abbas et. al., 2011). Debt sustainability has become a key concern for institutions like the International Monetary Fund (IMF) and World Bank because of the experiences of countries in the euro zone like Greece and Spain.

On the other hand, budget, current account, and savings investments deficits are deemed to make more money available to people in the economy who can buy and invest.Additionally, deficits are deemed to speed up capital investments by the government through the provision of infrastructure, education, health, and improved standards of living, all of which contribute to economic growth (Odhiambo and Momanyi, 2013). It therefore becomes important for policy makers to know where Kenya falls on this paradigm so that well informed policies that foster economic growth are adapted. This is key because one of Kenya's goals is to become an upper middle-income country and for this to be possible, it must attain and sustain GDP levels of $8.5 \%$ as recommended by the IMF (EAC, 2017).

\section{MAIN OBJECTIVE}

The main objective of this study was to determine the effect of triple deficits on economic growth in Kenya.

\section{A. Specific Objectives}

i. To establish the effect of budget deficits on economic growth in Kenya.

ii. To establish the effect of current account deficits on economic growth in Kenya.

iii. To establish the effect of savings investments deficits on economic growth in Kenya. 


\section{THEORETICAL REVIEW}

\section{A. Keynesian Theory}

The Keynesian theory was advanced by British economist, John Maynard Keynes in the 1930s during the period of the great depression. Keynes suggested that the only way the economy could be stimulated was through government intervention. The Keynesian theory is hinged on two assumptions, first, it allows for the possibility that some economic resources are unemployed and secondly, it allows for the possibility of crowding out of private investment (Saleh, 2004). This means that Keynesian analysis implies that budget deficits can either be advantageous or detrimental to economic growth. (Keynes, 1936) proposed that government intervention in economic activity can help spur long term economic growth by ensuring efficiency in resource allocation, regulation of markets, stabilization of the economy and harmonization of social conflicts.

This means that the government can therefore intervene to stimulate economic growth by correcting market failures that lead to budget deficits by altering either government expenditures or taxes (Odhiambo et. al., 2013). Keynes further argued that in some instances, especially during a slump, budget deficits can be good for an economy and ultimately lead to economic growth. (Keynes, 1936) argued that if an exogenous shock, like the great depression which began because of the stock market crash of 1929 was to occur, the government can increase its expenditure to increase aggregate demand and ultimately foster economic growth at the cost of running a budget deficit. Keynes therefore supported deliberate budget deficits by the government as the assumption was that the government would borrow money to finance the deficit and spend the money on public works which in turn would create jobs and increase the purchasing power of individuals (Eisner, 1989).

(Krugman, 1994) was however opposed to this line of thought as he argued that the assumption that the government would fine tune fiscal policy was far-fetched. $\mathrm{He}$ argued that there was a very high possibility that these so-called deliberate budget deficits could also be detrimental to economic growth through the crowding out effect and a rise in inflation. Crowding out effect is where private investors are locked out because of increased interest rates brought about by government borrowing. (Hermes and Lensink, 2001) also stated that the relationship between budget deficits and economic growth revolves around three issues, the crowding out effect brought on by high interest rates, accumulation of public debts and the fear that the government may resolve to money printing which would result to inflation tax all of which may hamper growth.

The relevance of this theory to this study is borne by the fact that in many economies, the Keynesian school of thought lays the basis for economic policies. The theory gives an in-depth insight into the effect of budget deficits on economic growth. Understanding this relationship will help inform on the appropriate economic policies to be adopted to foster economic growth.

\section{B. Thirlwall's Theory}

Thirlwall's model was advanced by Anthony Thirlwall in 1979. (Thirlwall, 1979) proposed that the rate of economic growth of a specific country is restrained by the current account as the economy cannot grow faster than the current account equilibrium or at least consistent with a sustainable deficit in the current account. The basic idea of this model is that export performance and import behavior play a huge role in determining long term economic growth. This model was based on three assumptions; trade balance is in equilibrium in the long run, price effects are negligible and do not affect equilibrium long run growth rates and foreign income growth positively affects domestic income.

(Soukiazis et. al., 2012) found that increasing foreign exchange revenue from exports is the only way to finance increasing imports caused by expanding economic activity. The interpretation of this is that current account deficits restrict the rate of economic growth to a level that is consistent with a sustainable position in the external sector (Andersen, 1993). (Sun and Heshmati, 2010) found strong evidence that international trade has a positive impact on economic growth by facilitating capital accumulation, modernization of industrial structure, technological and institutional progress. (Wagner, 2007) proposed that promoting exports fosters more intense competition and therefore improved productivity risk. (Thirlwall and Hussain, 1982) later extended this model to allow for the influence of foreign capital flows on economic growth. (Kvedaras et. al., 2020) contributed to this analysis by decomposing economic growth rates and a cyclical growth term caused by net capital inflows. In recent years, (McCombie and Thirlwall, 1994) and (Moreno, 2003) further revised this theory to ensure that the economy's long run growth is consistent with a sustainable path of foreign indebtedness.

This theory is therefore relevant to this study in that it recognizes the fact that current account deficits affect economic growth. It proposes that Kenya's rate of economic growth is restrained by the current account balance. Kenya's economy cannot grow faster than what is consistent with the current account equilibrium and in the case where current account deficits are inevitable, it cannot grow unless sustainable deficits are maintained.

\section{Endogenous Growth Model}

The emergence of endogenous growth models in the 1980s brought about a great interest in the link between savings, investments, and economic growth. Consequently, studies by (Jovanovic, 1990), (Bencivenga and Smith, 1991), (Roubini and Sala-I-Martin, 1992), (King and Levine, 1993) used these endogenous models to examine the interaction between savings and investments with economic growth. This study will focus on the model propagated by 
Marco Pagano in 1993. (Pagano, 1993) model argued that savings and investments are positively related to economic growth. He described the three channels that this could happen as: reduction in transaction costs, channeling of increased savings to firms for productive investments, improving the allocation of capital and the rate of savings. The theory also highlights the important role played by efficient financial institutions in domestic savings and investments in an economy. (Pagano, 1993) argued that the only way savings and investments could influence economic growth is if there were efficient financial institutions existing in an economy.

(King and Levine, 1993) predicted that financial institutions increase the productivity of investments and therefore contribute to economic growth by: efficiently evaluating projects and selecting the most promising ones and pooling household savings and mobilizing them to finance more promising projects. (Bencivenga and Smith 1991) also predicted that financial institutions reduce cash holdings in an economy thus contributing to more investments hence economic growth. (Roubini and Sala-IMartin, 1992) empirically showed that financial repression leads to high rates of inflation and a reduction in the productivity of capital which reduces economic growth rates.

This theory is relevant to this study because it explains how savings and investments determine the level of economic growth in Kenya. Increasing the rate of savings in an economy with efficient financial institutions will have the effect of increasing the output level in that economy. avings free up resources that can be employed to raise the productive capacity of an economy through effective financial institutions. This means that savings investments deficits will have a negative effect on economic growth.

\section{EMPIRICAL REVIEW}

\section{A. Budget Deficits and Economic Growth}

(Baldacci et. al., 2003) studied the use of fiscal policy in spurring growth in thirty-nine low-income countries with IMF supported adjustments programs for the period 1990 to 2001 using the generalized method of moments (GMM) model. They found that a $1 \%$ reduction in budget deficits had a positive and significant impact on the rate of real GDP growth rate. The study further found that fiscal policy must be tailored as per country specific conditions to encourage economic growth. The study concluded that a uniform approach in which all the countries under study are advised to reduce their budget deficits was found to be ineffective. This is because they found that budget deficits were both advantageous and detrimental to some of the countries under study.

(Huyuh, 2007) analyzed the effects of budget deficits on the GDP growth for the period 1990 to 2006 for developing Asian countries. The model used was ARDL approach. The study found that budget deficits significantly and negatively affect economic growth. As budget deficits increase, economic growth slows down. The study additionally found that budget deficits lead to a crowding out effect.A study done in Romania for the period 1980 to 2010, (Ristil et. al., 2013) using regression analysis found a positive and significant correlation between economic growth rate and budget deficits in the long run especially during periods of an economic slowdown. The implication of this finding is that an increase in budget deficits will lead to economic growth in a country in the long run. Additionally, the study found that positive economic growth rates lead to extra resources which in turn result in a causality relationship between economic growth and budget deficits. They further recommended that in periods of growth, budget deficits should be discouraged at all costs.

(Odhiambo and Momanyi, 2013) studied the relationship between fiscal deficits and economic growth in Kenya for the period 1990 to 2007. They employed the vector error correction model (VECM) approach and used a classical production function. Their findings showed that budget deficits increase economic growth because deficits enhance productivity through the provision of infrastructure, education, and health. They concluded that a positive and significant relationship exists between budget deficits and economic growth.

\section{B. Current Account Deficits and Economic Growth}

(Akbas et. al., 2014) conducted a study to analyse the relationship between current account deficits, short term capital flows and economic growth in emerging market economies for the period 1960 to 2012 using panel data analysis. They found that there was a positive and significant relationship between current account deficits and economic growth. The implication of this finding is that an increase in current account deficits will lead to an increase in economic growth. Additionally, they found bidirectional causality between current account deficits and economic growth.

(Aydin and Esen, 2016) carried out a study investigating the existence of threshold effects on current account deficits on economic growth in Turkey using quarterly data from 1999 to 2014. They used threshold autoregressive models where they found evidence of threshold effects at $4 \%$. This meant that any current account ratio above $4 \%$ negatively impacted economic growth while a ratio below the $4 \%$ positively affected economic growth. In conclusion, the study found that current account deficits were only beneficial to economic growth to some point, 4\%, after which any increases in current account deficits would automatically lead to low rates of economic growth.

(Rossitsa, 2014) examined the effects of current account imbalances on a sample of 179 countries covered by IMF data during the 2008-2009 global financial crisis. The countries were divided into high-income and low-income countries. The results showed a negative and insignificant 
effect of current account deficits on economic growth for low-income countries, for the high-income countries, the results showed positive and significant effect of current account deficits on economic growth. The findings indicated that current account deficits do not affect economic growth in low-income countries. However, for high income countries, current account deficits will lead to increased economic growth.

\section{Savings Investments Deficits and Economic Growth}

(Verma and Wilson, 2005) studied the relationship between savings, investments, foreign inflows, and economic growth in India. The study used autoregressive distributed lag (ARDL) model and annual time series data from 1950 to 2001 . The results revealed that savings and investments do not affect economic growth in themselves, rather, savings investments are a derivative of economic growth in both the short run and long run. The empirical findings showed a negative and insignificant relationship between savings investments balance and economic growth. Their results did not support the endogenous growth model that advocates for an increase in household savings vis-a-vis investments to foster economic growth.

(Budha, 2012) using the autoregressive distributed lag (ARDL) model and granger causality model tested for the relationship between gross domestic savings, investments, and economic growth in Nepal for the period 1975 to 2010. The study showed that co-integrating relationship existed between the three variables. For both the short and long run, the study found that the savings investments balance had a negative but insignificant effect on economic growth meaning savings investments balances do not affect economic growth of a country in the short and long run. The causality results showed that there was short and long run causality between investment and economic growth and between domestic savings and investments.

(Mohamed, 2014) investigated the causal relationship between savings, investments and economic growth in Ethiopia using annual time series data from 1970 to 2011 in a multivariate model. He used the autoregressive distributed lag (ARDL) model in his study. The results indicated that a long run relationship existed between savings, investments and economic growth proxied by gross domestic product (GDP) when GDP was the dependent variable. He found a significant positive effect of savings investments balances on economic growth in both the long run and short run. The study concluded that sustainable savings investments deficits increase the rate of economic growth in Ethiopia.

\section{METHODOLOGY}

\section{A. Research Design}

The study employed a descriptive research design. A descriptive research design was preferred because of its accuracy in describing and measuring the variables in a study. By using a descriptive research design, the study was able to accurately describe and detect any associations between budget deficits, current account deficits, savings investments deficits and economic growth which was proxied by real GDP. As a result, the study was able to establish how triple deficits affect economic growth in Kenya.

\section{B. Population of Study}

A population is referred to as the sum of all the elements from which the researcher intends to make inferences on (Sekaran, 2006). The target population for this study is annual data for budget deficits, current account deficits, savings investments deficits and real gross domestic product (GDP) over a 29-year period spanning from 1990 to 2018.

\section{Data Collection Procedure}

The study relied solely on secondary annual data for a 29year period. The study used time series data from 1990 to 2018. This data was obtained from several financial statistics publications issued by the government of Kenya, the International Monetary Fund and World Bank data banks. A data collection sheet was designed to help organise the data.

\section{Definition and Measurement of Variables Budget Deficits}

Budget deficits occur when government spending exceeds total revenue (Osoro, 2014). Annual budget deficits data in US dollars was obtained from the IMF financial statistics database and Government of Kenya publications.Due to the large variations in absolute data, annual values of budget deficits were transformed to natural $\operatorname{logs}$ to meet the condition of normality.

\section{Current Account Deficits}

Current account deficits in this study refers to a situation where a country's imports and net transfers abroad exceed the total exports and transfers from abroad (IMF,2020). Annual current account deficit data in US dollars was obtained from the World Bank database. Due to the large variations in absolute data, annual current account deficit values were transformed into natural logs.

\section{Savings Investments Deficits}

Savings investments deficits refer to a situation in which domestic investments exceed domestic savings (World Bank, 2020). Annual data for domestic savings and domestic investments proxied by gross capital formation in US dollars were obtained from the World Bank database. Due to the large variations in absolute data, annual savings investments deficit values in USD were transformed into natural logs.

\section{Real Gross Domestic Product}

Real gross domestic product is the total value of all the final goods and services produced in an economy during a given year adjusted for inflation (World Bank, 2020). In this study, real GDP is used as a measure of economic growth as 
used in studies by (Jalil and Feridun, 2011), (Kargbo and Adamu, 2010), and (Ghatak and Siddiki, 1999). The data used for real GDP was the GDP, PPP (constant 2017 international \$) in US dollars obtained from the World Bank database. The base year was 2017. Due to the large variations in absolute data, annual values of real GDP were also transformed into logs.

\section{E. Model Specification}

The general empirical model used in the study was defined by equation 1.1 as follows:

$$
R G D P_{t}=\alpha_{0}+\beta_{1} B D_{t}+\beta_{2} C A D_{t}+\beta_{3} S I D_{t}+\varepsilon_{t}(1.1)
$$

\section{Where:}

RGDP is real gross domestic product at time $t$.

$\mathrm{BD}_{\mathrm{t}}$ isbudget deficits at time $\mathrm{t}$.

$\mathrm{CAD}_{\mathrm{t}}$ is current account deficits at time $\mathrm{t}$.

$\mathrm{SID}_{\mathrm{t}}$ is savings investments deficits at time $\mathrm{t}$.

$\propto_{0}$ is the intercept.

$\beta$ are the coefficients of the explanatory variables.

$\varepsilon_{\mathrm{t}}$ is the composite error term of the model.

$\mathrm{t}$ is years ranging from 1990 to 2018

The autoregressive distributed lag (ARDL) and error correction models (ECM) were used to check for the existence of long run and short run relationships for the variables. The ARDL-ECM model was preferred because all the variables in the model do not need to be integrated of the same order, it can therefore be applied when the variables are integrated of order zero or one (Pesaran et. al., 2001). Secondly, ARDL bounds test is more efficient in cases where the data sample is small and finite. Lastly, ARDL bounds test gives unbiased estimates of the long run model (Harris and Sollis, 2003).

Equations 1.2 and 1.3 below show the long run and short run relationships respectively:

Equation 1.2:

$$
\begin{aligned}
R G D P_{t}=\alpha_{0}+\sum_{i=1}^{m} & \alpha_{1 i} R G D P_{t-i}+\sum_{i=0}^{m} \alpha_{2 i} B D_{t-i} \\
& +\sum_{i=0}^{m} \alpha_{3 i} C A D_{t-i}+\sum_{i=0}^{m} \alpha_{4 i} S I D_{t-i}+\varepsilon_{t}
\end{aligned}
$$

Equation 1.3:

$$
\begin{aligned}
\Delta R G D P_{t}=\beta_{0}+ & \sum_{i=1}^{m} \beta_{1 i} \Delta R G D P_{t-i}+\sum_{i=0}^{m} \beta_{2 i} \Delta B D_{t-i} \\
& +\sum_{i=0}^{m} \beta_{3 i} \Delta C A D_{t-i}+\sum_{i=0}^{m} \beta_{4 i} \Delta S I D_{t-i} \\
& +\lambda E C T_{t-1}+\mu_{t}
\end{aligned}
$$

Where:

RGDPis real gross domestic product.

$\mathrm{BD}_{\mathrm{t}}$ isbudget deficits.

$\mathrm{CAD}_{\mathrm{t}}$ is current account deficits.

$\mathrm{SID}_{\mathrm{t}}$ is savings investments deficits. $\lambda E C T_{t-1}=$ is the error correction term. The coefficient, $\lambda$, must be statistically significant and negative for the model to converge to equilibrium.

$\sum_{\mathrm{i}=0}^{\mathrm{m}}=$ is the sum of lagged components of variables.

\section{RESULTS AND DISCUSSIONS}

\section{A. Descriptive Statistics}

The summary of the descriptive analysis for the absolute values is discussed in Table 1 below.

Table I: Descriptive Statistics

\begin{tabular}{lllll}
\hline Variables & RGDP & BD & CAD & SID \\
\hline Mean & 120,260 & $-1,624.7$ & $-1,995.7$ & -2036.5 \\
Median & 103,482 & -773.7 & $-1,578.2$ & -868.4 \\
Max. & 216,046 & -91.9 & 132.4 & $1,124.2$ \\
Min. & 76,154 & $-6,474.6$ & $-6,377.9$ & $-8,220$ \\
Std. Dev & 42,484 & $2,046.4$ & $1,967.4$ & $2,765.5$ \\
Skew. & 0.4792 & 2.0114 & 3.2101 & 1.2964 \\
Kurt. & 1.9214 & 7.9438 & 15.2382 & 2.9493 \\
Jacque-Bera & 2.5154 & 49.0899 & 230.7870 & 8.1267 \\
Probability & 0.2843 & 0.0000 & 0.0000 & 0.0171 \\
\hline
\end{tabular}

Real GDP in Kenya averaged USD 120,261 million for the period 1990 to 2018. In this period, Kenya registered the highest economic performance with a maximum of USD 216,046 million. The high economic performance could have been because of major economic reforms that were implemented during the period like conservative fiscal and monetary policies, retrenchment, elimination of price and foreign exchange controls and privatization of publicly owned companies (Osoro, 2014). In theperiod 1990 to 2018, Kenya recorded the worst economic performance with minimum values of USD 76,154 million. The low economic performance can be attributed to political instabilities, systemic failures, and corruption (Lomulen, 2019).

In the period 1990 to 2018, budget deficits in Kenya averaged negative USD 1,624 million with a maximum surplus of USD 91.9 million and minimum values of negative USD 6,474 million.(Kariuki, 2017) majorly attributes persistent budget deficits experienced in Kenya to weak tax administrations, increased government expenditure on infrastructure and corruption. Current account deficits in Kenya for the period 1990 to 2018 averaged negative USD 1,995 million, with maximum values indicating a current account surplus of USD 132 million and minimum values indicating a deficit of negative USD 6,377 million. This indicates persistent current account deficits recorded in Kenya for the period under study. This is largely attributed to the over-reliance on the export of a few agricultural commodities that are largely dependent on international prices, fluctuations in oil prices and an increase in imports of manufactured and capital goods (Ahmad and Aworinder, 2015). The surplus was because of decreased imports brought on by a sluggish economy coupled with an increase in horticulture earnings (AfDB, 2004). 
Savings investments deficits in Kenya for the period 1990 to 2018 averaged negative USD 2,036 million, with maximum values indicating a surplus of USD 1,124 million and minimum values indicating a deficit of negative USD 8,220 million. This indicates persistent savings investments deficits for Kenya in the period under study. (Osoro et. al., 2014) attributes this to low incomes and the reluctance of the Kenyan government to formulate policies that encourage domestic savings. The surplus was because of increased savings brought on by economic reforms (Arok, 2014).The JarqueBerafindings above indicate that real GDP (J$\mathrm{B}=2.5154, \mathrm{p}=0.2843>0.05)$ was normally distributed but budget deficits $(\mathrm{J}-\mathrm{B}=49.0899, \mathrm{p}=0.0000<0.05)$, current account deficits $(\mathrm{J}-\mathrm{B}=230.7870, \mathrm{p}=0.000<0.05)$ and savings investments deficits $(\mathrm{J}-\mathrm{B}=8.1267, \mathrm{p}=0.0171<0.05)$ were not normally distributed. As a result, the data was normalized by transforming into logarithmic form.

\section{B. Normality Tests}

Since data was transformed to natural $\operatorname{logs}$, it became paramount to ensure that all the variables were now normally distributed. This study adopted the JarqueBera test of normality. The criterion for this test examines whether the $\mathrm{p}$ value is less than 0.05 .

Table II: Normality Test Results

\begin{tabular}{lllll}
\hline & LNRGDP & LNBD & LNCAD & LNSID \\
\hline Jarque-Bera & 3.6686 & 5.1158 & 3.4297 & 5.3547 \\
Probability & 0.1597 & 0.0889 & 0.1799 & 0.0687 \\
\hline
\end{tabular}

The test results showed that the log of real GDP (LNRGDP) $(\mathrm{J}-\mathrm{B}=2.5154$, Prob $=.2843)$, the log of budget deficits $(\mathrm{LNBD})(\mathrm{J}-\mathrm{B}=5.1558$, Prob $=.0889)$, the $\log$ of current account deficits (LNCAD) (J-B = 3.4297 and the $\log$ of savings investments deficits (LNSID) $(\mathrm{J}-\mathrm{B}=5.3547$, Prob $=0.0687$ )all had $\mathrm{p}$ values greater than 0.05 hence the null hypothesis of normal distribution was accepted.

\section{Correlation Analysis}

The research conducted correlation analysis using Spearman's rank correlation coefficient to establish the type of association between the triple deficits and economic growth in Kenya. The correlation tests have values ranging from -1 to +1 which are an indication of the strength of the interaction between the study variables.

Table III: Correlation Results

\begin{tabular}{lllll}
\hline & RGDP & BD & CAD & SID \\
\hline GDP & 1 & & & \\
BD & -0.5583 & 1 & & \\
& $\mathrm{P}=0.0001$ & & & \\
CAD & -0.4406 & 0.1580 & 1 & \\
& $\mathrm{P}=0.0167$ & $\mathrm{P}=0.4129$ & & 1 \\
SID & -0.5409 & 0.3066 & 0.0343 & \\
& $\mathrm{P}=0.0021$ & $\mathrm{P}=0.1050$ & $\mathrm{P}=0.8594$ & \\
\hline
\end{tabular}

Note: These are results for the logged values
Budget deficits, current account deficits and savings investments deficits all had negative and significant correlation with economic growth in Kenya.

\section{Serial Correlation Test}

The residual serial correlation test helps determine whether the error term for one period is correlated with the error term for a subsequent period. Breusch-Godfrey serial correlation LM test was used. The decision criterion is if $p$ value is greater than 0.05 , the null hypothesis cannot be rejected.

Table IV: Serial Correlation Results

\begin{tabular}{lll}
\hline Lags & Obs $^{*}$ R-squared & Prob.Chi-Square(2) \\
\hline 1 & 0.6404 & 0.4235 \\
\hline
\end{tabular}

The $\mathrm{p}$ value of observed R-squared (0.6404) is (0.4235) which is greater than 0.05 meaning the model does not suffer from serial correlation.

\section{E. Heteroscedacity Test}

Heteroscedacity is a systematic change in the spread of the residuals over the range of measured values. The Breusch-Pagan-Godfrey test was used to test for the presence of heteroscedacity. The null hypothesis is the variance of the residuals is constant, homoscedacity. If the $\mathrm{p}$ value is greater than 0.05 the null hypothesis is not rejected.

Table V: Heteroscedacity Results

\begin{tabular}{ll}
\hline Obs ${ }^{*}$ R-squared & P.Chi-Sq.(2) \\
\hline 5.1707 & 0.3954 \\
\hline
\end{tabular}

The $\mathrm{p}$ value of observed R-squared (5.1707) is 0.3954 which is greater than 0.05 therefore we cannot reject the null hypothesis of homoscedacity.

\section{F. Unit Root Tests}

The Augmented Dickey Fuller test was used to determine stationarity of the variables. The ARDL model requires that all variables be integrated of order zero $\mathrm{I}(0)$ or order one I(1). The null hypothesis for ADF test is the presence of unit roots. $\mathrm{P}$ values greater than 0.05 means presence of a unit root hence nonstationary while $\mathrm{p}$ values less than 0.05 means absence of a unit root hence stationary

Table VI: Unit Root Results at Level

\begin{tabular}{lll}
\hline Variable & T stat & Prob \\
\hline LNBD & -2.950 & 0.163 \\
LNCAD & -3.458 & 0.063 \\
LNRGDP & -1.339 & 0.856 \\
LNSID & -2.875 & 0.187 \\
\hline
\end{tabular}

From these results, all the variables, budget deficits, current account deficits, real GDP and savings investments deficit 
were nonstationary at level with $\mathrm{p}$ values of $0.163,0.063$, $0.856,0.187$ which were greater than 0.05 .

Table VII: Unit Root Results at $1^{\text {st }}$ Difference

\begin{tabular}{lll}
\hline Variable & T stat & Prob \\
\hline LNBD & -5.180 & 0.001 \\
LNCAD & -7.409 & 0.000 \\
LNRGDP & -4.501 & 0.006 \\
LNSID & -4.010 & 0.021 \\
\hline
\end{tabular}

The variables however all became stationary at first difference with $\mathrm{p}$ values of $0.001,0.000,0.006,0.021$ which were all less than 0.05 .

\section{G. Lag Order Selection}

Information Criteria namely, Akaike information criterion (AIC), Schwarz information criterion (SC), Hannan- Quinn (HQ) and Likelihood ratio (LR) were used to determine the number of lags. The optimum number of lags selected was 1 which was based on the AIC as it gave the lowest value among all the other information criterion.

\section{H. Cointegration Test}

The F-statistic bounds test was performed using a lag length of one. The null hypothesis $\left(\mathrm{H}_{0}\right)$ is that there is no cointegration between the variables. The decision criterion is to reject the null hypothesis if the F statistic falls above the upper bound and fail to reject the null hypothesis if the F statistic falls below the lower bound.

Table VIII: F Bounds Cointegration Results

\begin{tabular}{lcc}
\hline Sign. Level & I(0) & I(1) \\
\hline $1 \%$ & 3.17 & 4.14 \\
$5 \%$ & 3.79 & 4.85 \\
$10 \%$ & 5.15 & 6.36 \\
F-Statistic -9.6607 & \\
\hline
\end{tabular}

From the results above, the $\mathrm{F}$ statistic of 9.6607 is above the upper bounds limit I (1) of 4.14, 4.85 and 6.36 at the $1 \%$, $5 \%, 10 \%$ significance levels, respectively. This therefore means presence of cointegration. The study concludes that a long run relationship exists between real GDP, budget deficits, current account deficits and savings investments deficits.

\section{Regression Analysis}

The main objective of the study was to determine the effect of triple deficits on economic growth in Kenya. The study used the autoregressive distributed lag (ARDL) and error correction model (ECM) to capture the long run and short run effects of budget deficits, current account deficits and economic growth in Kenya.
1) Long Run Coefficients: Once co-integration was established, the long run coefficients of LNBD, LNCAD and LNSID were estimated using ARDL $(1,1,1,1)$ selected based on the Akaike information criterion.

Table IX: Long Run Coefficients

\begin{tabular}{lllll}
\hline Variable & Coefficient & $\begin{array}{l}\text { Std. } \\
\text { Error }\end{array}$ & $\begin{array}{l}\text { t- } \\
\text { Statistic }\end{array}$ & Prob. \\
\hline C & -0.9696 & 0.4807 & -2.0169 & 0.0573 \\
LNBD & -0.2573 & 0.1275 & -2.0181 & 0.0442 \\
LNCAD & -0.0913 & 0.0511 & -1.7865 & 0.2599 \\
LNSID & -0.0774 & 0.0765 & -1.0117 & 0.2670 \\
\hline R-squared -0.6982 & \multicolumn{4}{l}{ Prob (F stat) -0.000} \\
Durbin Watson stat- 1.747 & \multicolumn{4}{l}{} \\
\hline
\end{tabular}

$($ R-squared $=0.6982$, Prob. $=.0000<.05)$ means $69.82 \%$ of variations in real GDP which is a proxy for economic growth is explained by budget deficits, current account deficits and savings investments deficits in the long run in Kenya. The probability value of 0.0000 means that the $\mathrm{R}$ squared obtained was significant.The Durbin Watson test statistic was 1.7478 which is closer to 2 meaning the model had no problems of autocorrelation.The results above indicate that budget deficits (LNBD) had a coefficient of 0.2573 and a probability value of 0.0442 which is significant at the $5 \%$ level of significance. This indicates a negative and significant relationship between budget deficits and economic growth proxied by real GDP. A 1 unit increase in budget deficits will lead to a 0.2573 unit decrease in economic growth in Kenya. These results were in line with the findings by (Huyuh, 2007) in a study done on developing Asian countries. Current account deficits (LNCAD) and savings investments deficits (LNSID) had negative but insignificant effect on economic growth in Kenya in the long run. These findings indicate that current account deficits and savings investments deficits do not have a significant impact on economic growth in Kenya in the long run.

2) Short Run Coefficients: Using the long run estimates, the study obtained the short run dynamic parameters by estimating an error correction model.

Table X: Short Run Coefficients

\begin{tabular}{lllll}
\hline Variable & Coefficient & $\begin{array}{l}\text { Std. } \\
\text { Error }\end{array}$ & $\begin{array}{l}\text { t- } \\
\text { Statistic }\end{array}$ & Prob. \\
\hline C & -0.0030 & 0.0126 & -0.2424 & 0.8108 \\
DLNBD & -0.0010 & 0.0038 & -0.2631 & 0.7795 \\
$(-1))$ & & & & \\
$\begin{array}{l}\text { DLNCAD } \\
(-1))\end{array}$ & -0.0014 & 0.0006 & -2.3379 & 0.0423 \\
$\begin{array}{l}\text { DLNSID } \\
(-1))\end{array}$ & -0.0017 & 0.0064 & -0.2653 & 0.7933 \\
\hline $\begin{array}{l}\text { R-squared - 0.6460 } \\
\text { Durbin Watson stat }-1.697\end{array}$ & & & \\
\hline
\end{tabular}


$(\mathrm{R}$-squared $=0.6460$, Prob. $=.0003<.05)$ means $64.6 \%$ of variations in real GDP which is a proxy for economic growth is explained by budget deficit, current account deficits and savings investments deficits in the short run in Kenya.The probability value of 0.0003 means that the $\mathrm{R}$ squared obtained was significant. The Durbin Watson test statistic was 1.6972 which is closer to 2 meaning the model had no problems of autocorrelation. The results above indicate that current account deficits (LNBD) had a coefficient of -0.0014 and a probability value of 0.0423 which is significant at the $5 \%$ level of significance. This indicates a negative and significant relationship between current account deficits and economic growth in the short run. A 1 percent increase in current account deficits will lead to a 0.0014 percent decrease in economic growth in Kenya.These findings were consistent with findings by (Rossitsa, 2014) who studied a panel of 179 countries. Budget deficits (LNBD) and savings investments deficits (LNSID) had negative but insignificant effect on economic growth in Kenya in the short run. This means that budget deficits and savings investments deficits had no significant impact on economic growth in the short run.

3) Error Correction Estimate: The error correction term corrects for disequilibrium. It depicts the speed of adjustment towards the long run equilibrium after a shock. The larger the error correction term the greater the speed of adjustment from the short run to the long run.

Table XII: Error Correction Term

\begin{tabular}{lllll}
\hline Variable & Coefficient & $\begin{array}{l}\text { Std. } \\
\text { Error }\end{array}$ & $\begin{array}{l}\text { t- } \\
\text { Statistic }\end{array}$ & Prob. \\
\hline ECM(-1) & -0.4346 & 0.1285 & -3.3821 & 0.0028 \\
\hline
\end{tabular}

The coefficient of the error correction term (ECM(-1) (0.43 ) has a negative sign and is significant at the 5\% level. The negative and significant error correction coefficient provides additional evidence that the long run relationship is stable. The findings above indicate that approximately $43 \%$ annual disequilibria in economic growth (real GDP) from the previous year's shocks will converge in the long run equilibrium in the current year.

\section{J. Cumulative Sum of Recursive Residuals Test}

The cumulative sum of recursive residuals test,(CUSUM) test was used to determine the systematic movement in the model. The CUSUM statistic was plotted within the 5\% significance level.The plotted points should fluctuate around zero. If an upward or downward trend develops, it means the process mean has shifted and the process may be affected by special causes. Figure I shows the plotted points are fluctuating around zero meaning our model is stable.

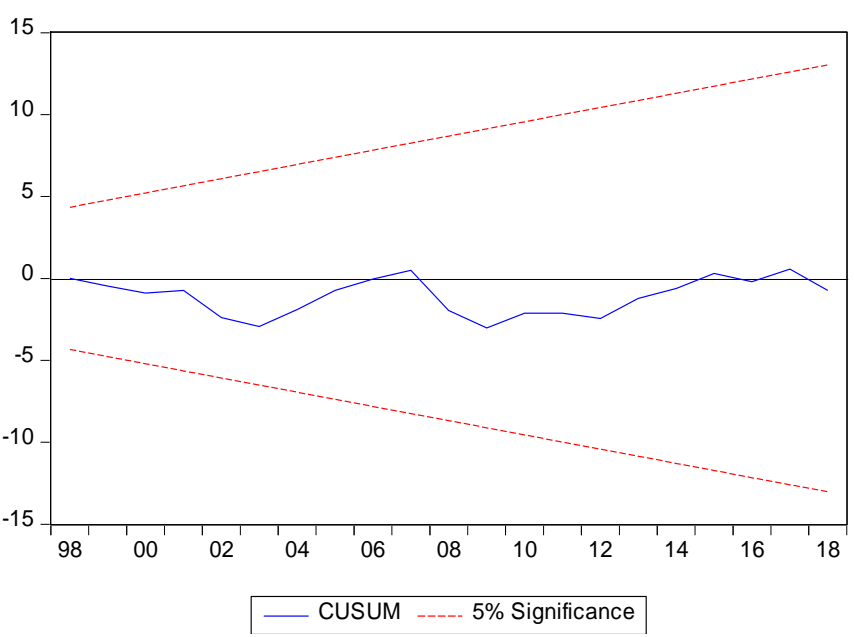

Figure 1: CUSUM Test Results

\section{K. Cumulative Sum of Recursive Residuals Squared Test}

The CUSUM squared test is more efficient than the CUSUM test in that it detects structural shifts. If the plotted points are outside the critical lines, that is an indication of presence of break points in the model which may call for introduction of dummy variables. Figure II however shows the plotted points were within the critical lines meaning the model was stable.

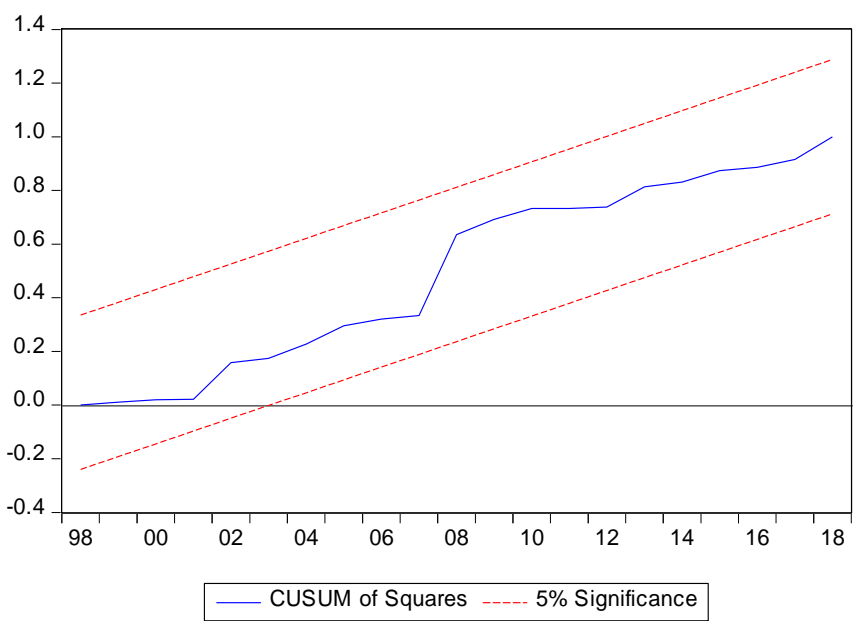

Figure 2: CUSUM Squares Test Results

\section{CONCLUSIONS}

The study was able to confirm the presence of a statistically significant influence of triple deficits on economic growth in both the short run and long run in Kenya. The first objective of the study was to establish the effect of budget deficits on economic growth in Kenya. The study concluded that budget deficits had a negative and insignificant effect on economic growth in the short run but a negative and significant effect on economic growth in the long run in Kenya. This means that increasing budget deficits in Kenya will hamper economic growth in the long run but not in the short run. The second objective examined the effect of current account deficits on economic growth in Kenya. The findings indicated a negative and significant effect on 
economic growth in the short run but a negative and insignificant effect on economic growth in the long run. This means that rising current account deficits will only lead to the deterioration of economic growth in the short run but have no effect in the long run.

The third objective examined the effect of savings investments deficits on economic growth in Kenya. The study concluded that savings investments deficits have a negative and insignificant effect on economic growth in both the short run and long run. The effect of this is that increasing savings investments deficits in Kenya will not negatively affect economic growth in the short run and long run. The study also concluded that speed of adjustment from disequilibria to long run equilibria in Kenya is moderate.Considering the findings, the study recommends formulation and adoption of policies that reduce budget deficits like widening of the tax base and encouraging greater budgetary discipline to reduce wastage and loss of funds through corruption. The study also recommends implementation of trade policies that promote exports. An example of such a policy would be concentrating on areas where Kenya has a comparative advantage, for example promoting value added agriculture as opposed to exporting raw agricultural produce which fetch much lower prices.

\section{REFERENCES}

1. Abbas, A.M., Hagbe, B.J., Fatas, A., Mauro, P., and Velloso, R.C. (2011). Budget policy and the current account. IMF Economic Review, 59(4), 603-629.

2. Adams, S., and Sakyi, D. (2012). Democracy, government spending and economic growth: The case of Ghana, 1960-2008. The Journal of Applied Economic Research, 6(3), 361-383.

3. African Development Bank. (2004). AfricanEconomic Outlook. [online].[Date accessed June 2021].

4. Ahmad, H., and Aworinde, O. (2015). Structural breaks and twin deficits in African countries. Economic Change Restruct, 48(1), 1-35.

5. Andersen, S.P. (1993). The 450-rule revisited. Applied Economics, 25(11), 1279-1284.

6. Arok, B.A. (2014). Determinants of gross domestic savings in Kenya, unpublished, Faculty of Economics, the University of Nairobi, Nairobi, Kenya.

7. Aydin, C., and Esen, A. (2016). The threshold effects of current account deficits on economic growth in Turkey: Does the level of current account deficit matter? International Journal of Trade, Economics and Finance, 7(5), 33-67.

8. Baldacci, E., Clements, B., and Gupta, S. (2003). Using fiscal policy to spur growth. Finance and Development, 82(1), 117-125.
9. Bencivenga, V.R., and Smith, B.D. (1991). Financial intermediation and endogenous growth. Review of Economic Studies, 58(2), 195-209.

10. Budha, B. (2012). A multivariate analysis of savings, investment, and growth in Nepal. Munich Personal Repec Archive.

11. East African Community. 4th Development strategy 2011/2012 - 2015/2016. [online]. Available from: www.eac.int/resources/documents/eacdevelopment-strategy-v4. [Date accessed: June 2021].

12. Eisner, R. (1989). Budget deficits: Rhetoric and reality. Journal of Economic Perspectives, 3(2), 73 93.

13. Ghatak, S., and Siddiki, J. (2001), The use of the ARDL approach in estimating virtual exchange rates in India. Journal of Applied Statistics, 28(5), 573-583.

14. Harris, R. and Sollis, R. (2003). Applied time series modelling and forecasting. Wiley Applications.

15. Hermes, N., and Lensink, R. (2001). Fiscal policy and private investment in less developed countries. University of Groningen, Netherlands.

16. Huyuh, N. (2007). Budget deficit and economic growth in developing countries: The case of Vietnam. Kansai Institute for Social and Economic Research.

17. International Monetary Fund. (2020). Strong reforms offer countries path to high income status. International Monetary Fund, [online]. Available from:https://www.imf.org/en/News/Articles/2015/0 9/28/04/53/socar121614a

18. Jalil, A., and Feridun, M. (2011), The impact of growth, energy and financial development on the environment in China: A cointegration analysis. Energy Economics, 33(2), 284-291.

19. Kariuki, S.N. (2017). Testing the fiscal, current, and financial accounts deficits nexus (Triplet deficits hypothesis) for Kenya, unpublished, Department of Economic Theory, Kenyatta University, Nairobi, Kenya.

20. Kargbo, S. M., and P. A. Adamu (2010). Financial development and economic growth in Sierra Leone. Journal of Monetary and Economic Integration, 9(2), 30-61.

21. Keynes, J.M. (1936). The general theory of employment, interest, and money. London: Macmillan,

22. Krugman, P. (1994). The myth of Asia's miracle. Foreign Affairs, 73(6), 62-78.

23. Lomulen, L.P. (2019). The effects of current account deficit on economic growth in Kenya, unpublished, Department of Economics, University of Nairobi, Nairobi, Kenya. 
24. McCombie, J.S., and Thirlwall, A.P. (1994). Economic growth and the balance of payments constrained growth. Economic Spring, 1997, 315375.

25. Milessi-Ferreti,, G., and Razin, A. (1996). Sustainability of persistent current account deficits. NBER working paper.

26. Mohammed, S. (2004). Testing the relationship between private savings and economic growth in Bahrain. Global Journal of Commerce and Management Perspective, 4(6), 1-6.

27. Moreno, J.C. (2003). Capital flows, interest payments and the balance of payments constrained growth model: A theoretical and empirical analysis. Metroeconomica, 54(2), 346-365.

28. Omondi, O.S., and Momanyi, G. (2013). The relationship between fiscal deficit and economic growth in Kenya. Greener Journal of Sciences.

29. Osoro, K.O., Gor, O.S. and Mbithi, L.M. (2014). Twin deficit and the macroeconomic variables in Kenya. International Journal for Innovation Education and Research, 2(09), 64-85.

30. Osoro, S. (2016). Effects of budget deficit on economic Growth in Kenya, unpublished, University of Nairobi, Nairobi, Kenya.

31. Pagano, M. (1993). Financial markets and growth. European Economic Review, 37, 613-622.

32. Pesaran, M. H. and Shin, Y. (1999). An autoregressive distributed lag modeling approach to co-integration analysis. Cambridge University Press.

33. Pesaran, M. H., Shin, Y., and Smith, R. C. (2001). Bounds testing approaches to the analysis of level relationships. Journal of Applied Economics, 16(1),289-326.

34. Ristil, C., Nicolaescu, C., and Tagaduan, D. (2013). Budget deficit effects on economic growth. Journal of Economics and Business Research, 2, 321-356.

35. Roubini, N., and Sala-I-Martin, X. (1992). Financial repression and economic growth. Journal of Development Economics, 11(39), 5-30.

36. Saleh, A.S. (2004). The budget deficit and economic performance. University of Wollongong Economic Working Paper Series.

37. Şen, H., and Kaya, A. (2016). Are the twin or triple deficits hypotheses applicable to post-communist
countries?.BOFIT Discussion Papers, Bank of Finland, 3.

38. Sun, P., and Heshmati, A. (2010). International trade and its effects on economic growth in China. Discussion Paper No. 5151, IZA, Institute for the Study of Labor.

39. Thirlwall, A.P. (1979). The balance of payments constraint as an explanation of international growth rate differences. BancaNazionale Del Lavoro Quarterly, 128, 44-53.

40. Thirlwall, A.P., and Hussain, M.N. (1982). The balance of payments constraint, capital flows and growth rates differences between developing countries. Oxford Economic Papers, 34(3), 498510.

41. Verma, R., and Wilson, E. (2005). Savings, investment, and growth in India: An appreciation of the ARDL bounds testing approach. South Asia Economic Journal, 8(1), 87-98. 